\title{
MomentDergi
}

Hacettepe Üniversitesi Illetişim Fakültesi Kültürel Çalışmalar Dergisi

2019, 6(1): 9-37

ISSN: 2148-970X.

Makaleler (Tema)

\section{OTORITARYEN POPÜLIZM VE AMERIKAN AJITATÖRÜNÜN YENI PORTRESI: NICHOLAS J. FUENTES}

\section{Tuğba Taş*}

\section{Öz}

Frankfurt Okulu düşünürleri otoritaryenliğe ilişkin araştırmalarını 1930'lu ve 1940'lı yıllarda yapmışlardır. Theodor W. Adorno ile Leo Lowenthal ve Norbert Guterman'ın araştırmaları ve analizlerinde ortaya koydukları "otoritaryen kişilik"ler, ajitatörler ve demagogların söylemiyle günümüzde ABD'deki siyasi liderlerin resmi olmayan sözcülerinin yeni medyadaki söylemleri arasında paralellikler bulunmaktadır. Bu anlamda Frankfurt Okulu düşünürlerinin otoritaryenizm teorisinin günümüzün otoritaryen popülist söylemini eleştirel bir şekilde analiz etmemize yardımcı olacağı düşünülmektedir. Bunun için öncelikle otoritaryen popülizm kavramı tartışılacak, ardından elitleri, beyaz olmayan tüm insanları, göçmenleri, Müslümanları, Yahudileri ve komünistleri, beyaz Hıristiyan Amerika'nın mevcut önyargılarını kullanarak düşman olarak etiketleyen yeni medya kişiliği Nicholas J. Fuentes' in söylemi analiz edilecek; otoritaryenlik ve anti-Semitizm üzerine yapılan ilk dönem araştırmalar, çevrimiçi haberlerde ve sosyal medyada "sahte peygamberler"in yeni söylemiyle karşılaştırılacaktır

\section{Anahtar Terimler}

otoritaryen popülizm, Frankfurt Okulu, sahte peygamberler, ajitatör, ABD.

* Doç. Dr., Ankara Üniversitesi İletişim Fakültesi

ORCID ID: 0000-0003-0948-1683, tugbakanli@yahoo.com

Makalenin Geliş Tarihi: 5/03/2019 Makalenin Kabul Tarihi: 23/04/2019

(C) Yazar(lar) (veya ilgili kurum(lar)) 2019. Atıf lisansı (CC BY-NC 3.0) çerçevesinde yeniden kullanılabilir. Ticari kullanımlara izin verilmez. Ayrıntılı bilgi için açı erişim politikasına bakınız. Hacettepe Üniversitesi İletişim Fakültesi tarafından yayınlanmıştır. 


\title{
AUTHORITARIAN POPULISM AND THE NEW PORTRAIT OF THE AMERICAN AGITATOR: NICHOLAS J. FUENTES
}

\begin{abstract}
The Frankfurt School philosophers made research on authoritarianism in the 1930s and 1940s. However, there are parallels between the discourse of agitators and demagogues in the research and analyses of Theodor W. Adorno, Leo Lowenthal and Norbert Guterman, and the discourse of the informal spokesperson of the political leader in the US today. In this sense, the critical theory of authoritarianism advanced by Frankfurt School help us to critically analyze today's authoritarian populist discourse. Thus in this paper firstly the concept of authoritarian populism will be discussed, then the discourse of the new media personality Nicholas J. Fuentes, who labeled the elites, all non-white people, immigrants, Muslims, Jews and communist as enemies, using white Christian America's current prejudices will be analyzed, and early research on authoritarianism and anti-Semitism will be compared with "new" discourse of the "false prophets" in online news and social media.
\end{abstract}

\section{Key Terms}

authoritarian populism, Frankfurt School, false prophets, agitator, USA.

\section{Giriş $^{1}$}

Son yıllarda en çok tartışılan konulardan biri otoritaryen popülizmin dünya çapındaki yükselişi oldu. Amerika Birleşik Devletleri'nde Donald Trump'ın seçim kampanyası sırasında ve başkan seçildikten sonraki yabancı düşmanı ve ırkçı söylem ve uygulamaları tartışmaları alevlendirdi. Trump, 2016 başkanlık seçimini “Önce Amerika” ("America First”) ve "Amerika'yı Yeniden Büyük Yap" ("Make America Great Again") sloganlarıla yürütülen milliyetçi kampanyayla kazandı (Fuchs, 2018a, s. 1). Seçim öncesinde verdiği “Amerika'yı Yeniden Büyük Yap"ma “sözü"nü hayata geçirmek için uluslararası anlaşmaları yeniden değerlendiren, yasadışı göçmenleri sınır dışı etmek ve Müslümanların ülkeye girişini yasaklamak için çalışan Trump, ülkeye göçmen girişini engellemek için Meksika sınırına duvar inşa etme konusunda ısrar ediyor ve sınıra asker yığıyor. Amerika'yı yeniden büyük bir ülke yapma vaadinin arkasında siyahlara, Hispaniklere, göçmenlere kaptırdığını düşündüğü siyasi ve ekonomik üstünlüğü yeniden ele geçirerek "beyaz

\footnotetext{
${ }^{1}$ Makale konusunun geliştirilmesinden yazım sürecine kadar her aşamada fikir ve eleştirilerini cömertçe paylaşan değerli hocam Prof. Dr. D. Beybin Kejanlıŏlu'na sonsuz teşekkürlerimle.
} 
Amerika"y1 güçlendirme düşüncesi bulunuyor (Appadurai, 2017, s. 21).

$\mathrm{Bu}$ gidişatı analiz etmek için farklı açıklamalar yapılmakla birlikte günümüzde Frankfurt Okulu düşünürlerinin teorik mirası ve kavramlarına başvuran pek çok yazar bulunmaktadır (Kellner, 2016; Fuchs, 2018; Wolin, 2016; MacWilliams, 2016; Morelock, 2018; Kejanlığlu, 2018). Douglas Kellner (2016, s. 19) Trump çağının otoritaryen popülizmini, Trump'ın karakterini ve onun takipçilerine cazip gelen yanlarını analiz etmek için Frankfurt Okulu düşünürlerinden, özellikle de Erich Fromm'un kavramlarından faydalanırken Christian Fuchs (2018) internet çağında Donald Trump'ın söylemini analiz etmek için yine Frankfurt Okulu düşünürlerine başvurur. Richard Wolin ise (2016) Trump dönemini anlamak için özellikle Okul'un Studies in Prejudice (Önyargı Üzerine Çalışmalar) adlı araştırma projesinin çıktıları olan çalışmaların önemi üzerinde durur. Matthew C. MacWilliams (2016), Theodor W. Adorno vd.'nin The Authoritarian Personality (Otoritaryen Kişilik) (1950) başlıklı çalışmasından faydalanarak, bu eserin Trump destekçilerini anlamak ve analiz etmek için çok kullanışlı araçlar sunduğunu savunur ve Trump'a oy verenlerin belirleyici özelliklerinin "otoritaryen kişilik" olduğunu ortaya koyar. 2018 yılının sonunda Jeremiah Morelock'un editörlüğünde yayınlanan Critical Theory and Authoritarian Populism (2018) başlıklı derleme kitap ise Avrupa ve ABD'de otoritaryen popülizmin yükselişini doğrudan Frankfurt Okulu düşünürlerinin perspektifinden analiz eden makalelerden oluşur. D. Beybin Kejanlığlu (2018) okul düşünürlerinden Leo Lowenthal ve Norbert Guterman'ın Prophets of Deceit: The Study of the Techniques of the American Agitator (Aldatmanin Peygamberleri: Amerikan Ajitatörünün Teknikleri Üzerine Bir Çalışma) (1949/1970) çalışmaları ile Theodor W. Adorno'nun The Psychological Technique of Martin Luther Thomas' Radio Addresses (Martin Luther Thomas'ın Radyo Konuşmalarının Psikolojik Tekniği) (1943/2000) çalışmasında otoritaryenizmi $^{2}$ anlamak için geliştirdikleri kavramların günümüz otoritaryen popülizmini anlamak için son derece elverişli olduğunu belirtir.

Okul düşünürleri otoritaryenliği ve anti-semitizmi anlamak için dönemin en önemli iletişim aracı olan radyodaki konuşmalara odaklanmışlardır. Günümüzde ise radyonun yerini sosyal medya, çevrimiçi haber ve video paylaşım platformları almıştır. Luca Manucci'nin belirttiği gibi (2017, s. 568) sosyal medyanın popülist mesajların yayılması için üç nedenle mükemmel bir kanal olduğu söylenebilir. Öncelikle geleneksel medyanın ana

\footnotetext{
2 Theodor W. Adorno'nun Otoritaryen Kişilik çalışmasını Türkçe'ye çeviren Doğan Şahiner, kitaba yazdığı "Sunuş" metninde, sözlüklerde "otoritaryen" sözcügünün yer almadığını, ancak "otoriter" sıfatının otoriter yönetime açık ve yandaş kişiyi tanımlamak için uygun olmadığından, "authoritarian" sözcügünün karşılığı olarak "otoritaryen" terimini kullandığını belirtmiştir (2003, s. 10). Bu makalede de Şahiner'i takip ederek "authoritarian" sözcüğünü karşılamak için “otoritaryen” terimi kullanılmıştır.
} 
akım siyasi seçkinler tarafından kontrol edildiğini savunan popülist aktörler sosyal medyayı tarafsız ve bağımsız bir alan olarak görürler; ikincisi, sıradan insanlara hitap ettiği iddiasındaki popülist liderler için seçmenlerle doğrudan iletişim kurma imkânı bu imajlarını güçlendirir; üçüncü olarak, sosyal medyanın gayri resmi olması popülizmin söylemsel biçimine yakındır.

Popülistlerin her zaman aracıları ortadan kaldırmak istediklerini belirten Jan-Werner Müller, popülistlerin medyayı da bir aracı olarak gördüğünü ve medyayı "araya girmek" ile suçladığını söyler (Müller, 2018, s. 52). Aynı durum sosyal medya için geçerli değildir. Fuchs'a göre temel iletişim araçları reality TV (The Apprentice) ve sosyal medya (Twitter) olan Trump, eski ideolojilerin yeni medyayla nasıl yayıldığının ve internet gösterisi çağında nasıl yeni biçimler aldığının tipik bir örneğidir (Fuchs, 2018, s. 6). Seçmenler Trump'a 2016 seçim kampanyası boyunca çok etkin biçimde kullandığı Twitter hesabı aracılığıyla "doğrudan" ulaşabilmiştir (Müller, 2018, s. 53).

Bununla birlikte sadece siyasi liderler değil, Lowenthal ve Guterman'ın ajitatör olarak tanımladığı "kendinden menkul" popüler medya kişilikleri de (Lowenthal ve Guterman, 1970: xv) yeni medyayı etkin bir şekilde kullanmaktadır. Günümüzde siyasi mesajlar Manucci'nin belirttiği gibi siyasi aktörler ve medya aktörlerinden oluşan bütünleşik bir sistem içinde üretilmektedir. Günümüzün sosyal medya ortamı "siyasi aktörler ile medya aktörleri arasındaki ayrımı bulanıklaştırır ve kullanıcı-türevli içeriklerin politik tartışmadaki rolünü ortaya koyar" (Manucci, 2017, s. 576).

Nicholas J. Fuentes, Trump destekçisi bir medya aktörüdür. Kendisini "milliyetçi Amerikan medya kişiliği" olarak tanitan Fuentes, America First with Nicholas J Fuentes isimli Youtube kanalında düzenli olarak program yapmaktadır. Ayrıca James Allsup ile birlikte Nationalist Review başlığıyla haftalık podcast yayını yapan Fuentes, Trump'ın seçim kampanyası sırasında mitinglerini YouTube'da canlı olarak yayınlayan ve "resmi olmayan Trump TV" (Borchers, 2016) olarak tanımlanan Right Side Broadcasting Network'e de [RSBN] katkıda bulunmuştur. Bu yazıda Fuentes'in Twitter sayfaları, Youtube kanalı, kişisel web sitesi ve çeşitli kişilere verdiği röportajlardaki söylemi analiz edilecektir. Bu doğrultuda otoritaryenizm ve anti-Semitizmin radyo konuşmalarındaki görünümüne ilişkin erken dönem çalışmaların, günümüz çevrimiçi haberlerinde ve sosyal medyadaki "sahte peygamberler"in (Lowenthal, 1987) "yeni" söylemini anlamak için kullanışlı olduğu düşünülmektedir. Lowenthal ve Guterman'ın (1949/1970) Amerika'daki otoritaryen popülist demagog/ajitatörlerin kullandıkları taktikleri anlamak üzere geliştirdikleri temalar ile Adorno'nun "otoritaryen sendrom" (1950) kavramı analiz için çerçeve oluşturacaktır. Bu 
çerçeve içinde, ajitatörün söyleminin içeriğini deşifre etmek; otoritaryen popülizmin siyasal alandaki gücünü söylemsel düzeyde nasıl ürettiğini, hangi araç ve taktikleri kullandığını anlaşılır hale getirmek ve 1940'ların Amerikasının ajitatörü ile günümüz ajitatörü arasındaki bağlantıyı serimlemek hedeflenmektedir.

\section{Otoritaryen Popülizmi Tanımlamak}

Frankfurt Toplumsal Araştırmalar Enstitüsü'nde 1930'lu ve 1940'lı yıllarda otoritaryenizme ilişkin yapılan çalışmaların günümüz otoriter popülizmine 1şık tutabileceğini söyleyebiliriz. Enstitü' nün özellikle dört çalışması doğrudan otoritaryenizm ile ilgilidir: Authority and The Family (Otorite ve Aile, Horkheimer vd. 1936/2002), The Psychological Technique of Martin Luther Thomas' Radio Addresses (Martin Luther Thomas'in Radyo Konuşmalarmnn Psikolojik Tekniği, Adorno, 1943/2000), Prophets of Deceit: The Study of the Techniques of the American Agitator (Aldatmanın Peygamberleri: Amerikan Ajitatörünün Teknikleri Üzerine Bir Çalışma, Lowenthal ve Guterman, 1949/1970) ve The Authoritarian Personality (Otoritaryen Kişilik, Adorno vd., 1950). ${ }^{3}$ 1930'ların sınıflı toplumunda otoritaryenizm kavramı baskılanmış işçi sınıfının neden baskıcı toplumsal düzene karşı hareket etmediğini ya da kitlelerin neden nesnel çıkarlarına aykırı hareket ettiklerini anlamak üzere ortaya çıkmıştır. Enstitü baskıcı toplumsal düzenin içselleştirilmesi, konformizm ve kitlelerin siyasi otoritelere irrasyonel bir şekilde boyun eğmesi ile ilgili analiz yaparken Freudyen ve Markist bir otoritaryenizm kavramı kullanmıştır (Kejanlığlu, 2018). Bunda, Wilhelm Reich ile bir dönem Enstitü'nün üyesi olan Erich Fromm'un çok önemli etkilerinin olduğunu söyleyebiliriz.

Reich'ın Character Analysis (Kişilik Çözümlemesi) ve The Mass Psychology of Fascism (Faşizmin Kitle Psikolojisi) başlıklı kitapları 1933 yılında yayınlanmıştır. Kişilik Çözümlemesi kitabında ortaya koyduğu "mazoşist karakter" Fromm ve Adorno'nun otoritaryenizm çalışmaları için merkezi öneme sahiptir. Faşizmin Kitle Psikolojisi kitabında geniş çaplı bir karakter, toplumsal yapı ve cinsellik analizi ortaya koyabilmek için Marks ve Freud'u birleştiren Reich'ın bu yaklaşımı o zamanlar için çok yenidir ve Frankfurt Okulu düşünürlerini derinden etkilemiştir (Morelock, 2018, s. xv). Amerikan Yahudi Komitesi'nin sponsorluğuyla Max Horkheimer yönetiminde yürütülen Studies in Prejudice (Önyargı Üzerine Çalışmalar) adlı araştırma projesi tam da böyle bir yaklaşımın ürünüdür. Beş ciltlik

\footnotetext{
3 Bu çalışma, Otoritaryen Kişilik Üstüne: Niteliksel İdeoloji İncelemeleri başlığıyla Türkçeye çevrilmiştir. Ancak çeviri orijinal çalışmanın bütününü değil sadece Adorno'nun yazdığı bölümü kapsamaktadır. bkz. Adorno, T.W. (2003) Otoritaryen Kişilik Üstüne: Niteliksel İdeoloji İncelemeleri. (çev.) Doğan Şahiner. İstanbul: OM Yayınevi.
} 
çalışmanın bir parçası olan 1949 tarihli Aldatmanın Peygamberleri eserinde Lowenthal ve Guterman, ajitatör olarak tanımladıkları kişilerin çeşitli retorik stratejilerini deşifre ederken onları yönlendiren içsel ve bazen bilinçdışı mekanizmaları değerlendirmiş olsalar da bunların sosyolojik bir perspektiften anlaşılması gerektiğini savunmuşlardır. Yazarlara göre hiçbir ajitasyon tekniğini politik ya da sosyal bağlamı dışında değerlendirmek mümkün değildir.

Fromm'un ilk dönem ampirik çalışmaları da modern kapitalist toplumun, otoriter kişiliğin en etkili güdüleyicisi olan, sado-mazoşizmi doğurduğunu ortaya koymuştur. Adorno, Freud'un kendisinin zaten sado-mazoşist kişiliğin temel hatlarını çizdiğini ama Fromm'un onu Marksist sosyal teori ile ilişkilendirdiğini söylemiştir (Rensmann, 2017, s. 67). Önyargı Üzerine Çalışmalar projesinin diğer bir parçası olarak 1950 yılında yayınlanan The Authoritarian Personality (Otoritaryen Kişilik), çalışması böyle bir yaklaşımı benimsemiştir. Theodor W. Adorno, Else Frenkel-Brunswik, Daniel Levinson ve Nevitt Sanford'in Amerika'da yaptıkları ampirik bir çalışmaya dayanan kitabın en önemli niteliği siyasal, toplumsal ve dinsel ideolojiyi kişisel özelliklerle birleştirerek kişilik ile ideoloji ilişkisine dikkat çekmesidir.

Adorno vd. araştırmalarını "potansiyel faşist" birey üzerine kurmuşlardır. Yazarların 'potansiyel' terimini kullanmalarının sebebi faşist olduğunu açıça ilan eden ya da faşist bir organizasyona üye olan bireyler üzerinde çalışmamalarıdır: "Verilerin çoğu toplandı̆̆ı zaman, faşizm henüz yenilgiye uğratılmıştı ve bu yüzden kendini açıkça böyle olduğunu ifade edebilecek birini bulmayı bekleyemezdik. Ama eğer faşizm güçlü ya da saygıdeğer bir toplumsal hareket olursa, onu kolayca kabul edebilecek bakış açısına sahip bireyleri bulmakta herhangi bir zorluk yoktu" (Adorno vd., 1950, s. 1). Araştırmanın temel soruları şöyleydi: Potansiyel olarak faşist bir birey varsa, bu birey tam olarak nasıl biridir? Antidemokratik düşünce hangi niteliklerden oluşur? Böyle bir bireyin içsel düzenleyici güçleri nelerdir? Böyle bir birey varsa, toplumda görülme sıklı̆̆ nedir ve belirleyicileri ve gelişiminin seyri nasıldır? (Adorno vd., 1950, s. 2).

Otoritaryen terimi sosyal psikoloji alanında "belirli türde kişisel yatkınlıklar ya da öğrenilmiş kültürel değerlere" göndermede bulunur (Norris ve Inglehart, 2019, s. 7). Nitekim araştırmacılar bireyin kişilik yapısına yönelmiş ve kişiliğin ideolojik tercihlerin belirleyicisi olarak kabul edilebileceğini söylemiş olsalar da bununla birlikte kişiliğin nihai bir belirleyici olarak sabitlenemeyeceğinin; kişiliğin baştan verili, sabit ve etrafındaki dünyaya etki eden bir şey olmaktan ziyade sosyal çevrenin etkisi altında geliştiğinin ve 
içinde bulunduğu toplumsal bütünlükten asla izole edilemeyeceğinin altını çizmişlerdir (Adorno vd., 1950, s. 5).

Adorno vd. kişilik yapısının, bireyi anti-demokratik propagandaya açık kılabileceğini söylerlerken hangi koşullar altında bu tarz propagandanın yükseleceğini, basında ve radyoda baskın hale gelebileceğini ve potansiyel olanın hangi koşullar altında aktifleşmeye başlayacağını da sorgular. Yazarlara göre cevap tekil bir kişilikte ya da kişilik faktörlerinde değil toplumun kendisinde aranmalıdır: "Bugün antidemokratik propagandanın baskın bir güç haline gelip gelmemesi öncelikli olarak en güçlü ekonomik çıkarların durumuna ve bu mekanizmayı hâkim durumlarını korumak için kullanıp kullanmadıklarına bağlıdır." Dolayısıyla sadece bireyin psikolojik yapısını değil, içinde yaşadığı toplumun nesnel durumunu da hesaba katmak gerekir (Adorno vd., 1950, s. 7-8).

Adorno vd. (1950, s. 228) araştırmalarında otoritaryen kişilik sendromunu saptamaya yarayan dokuz nitelik ortaya koymuşlardır:

- Gelenekçilik: Geleneksel, orta sınıf değerlerine katı bağlılık.

- Otoritaryen teslim: Ait olunan grubun, idealleştirilen ahlaki figürlerine yönelik itaatkâr, eleştirel olmayan tutum.

- Otoritaryen saldırganlık: Geleneksel değerleri ihlal eden insanları mahkûm etmeye, reddetmeye ve cezalandırmaya eğilim.

- Öznellik, yaratıcılık karşıtlığı.

- Batıl inanç ve basmakalıp yargı: Bireyin kaderinin mistik olarak belirlendiği inancı; katı kategoriler içinde düşünme eğilimi.

- Güç ve "sertlik": Hâkimiyet-boyun eğme, güçlü-zayıf, lider-takipçi ikilikleriyle düşünme; güç figürleriyle özdeşleşme; egonun geleneksel niteliklerine aşırı vurgu; abartılı dayanıklılık ve sertlik iddiası.

- Yıkıcılık ve sinizm: Genelleştirilmiş düşmanlık; insanın kötülenmesi.

- Yansıtmacılık: Dünyada vahşi ve tehlikeli şeylerin devam edeceğine inanma eğilimi; bilinçdışı duygusal dürtülerin dışarıya yansıtılması.

- Cinsellik: Cinsel faaliyetlerle ilgili abartılı bir endişe.

Matthew MacWilliams'ın çalışması bu niteliklerin günümüz için de geçerli olabileceğini göstermiştir. Trump destekçilerini anlamak ve analiz etmek için Adorno vd.'nin kavramlarından faydalanan ve 1800 seçmenle görüşen MacWilliams (2016) otoritaryen Amerikalıların Trump'ın başarısında kilit rol oynadığını söyler. Otoritaryen kişilerin dünyayı siyah-beyaz terimlerle algıladıklarını, düzen istedikleri, otoriteye karşı itaatkâr 
olduklarını, "öteki" nden korktuklarını ve "öteki"ne karşı saldırgan bir tavır takındıklarını söyleyen MacWilliams'a göre bu nitelikler günümüzde Trump seçmenleri için de geçerlidir.

Frankfurt Okulu düşünürlerinden yola çıkan Christian Fuchs'a $(2018$, s. 55) göre daha kapsamlı bir sağ otoritaryenizm anlayışının dört niteliği bulunmaktadır: (1) otoritaryen kişiler güçlü otoriteler ve liderlerin önemine inanırlar; (2) ulusu ya da etnisiteyi şekillendirdiği düşünülen belirli bir topluluğun üstünlüğüne inanırlar. Milliyetçilik ve dost/düşman tasarısı kapitalizmin yarattığı sınıf çatışmasının üzerini örtmek amaciyla öne sürülür; (3) Ulusal topluluk, karşı çıkılması, savaşılması ve bertaraf edilmesi gereken düşmanlar olarak tanımlanan bir ya da daha fazla sayıda dış grupla ilişkisi içinde inşa edilir; (4) Patriarkal ve militaristlerdir, muhafazakâr değerlere inanırlar. Toplumun zayıf ve güçlü ikiliğine dayalı olarak şekillendirildiğini, dünyanın daimî bir savaş tehdidiyle birlikte vahşi ve tehlikeli bir yer olduğunu ve ulusu düşmanlara karşı savunmak gerektiğini düşünürler (Fuchs, 2018, s. 53).

Norris ve Inglehart da bir değerler kümesi olarak tanımladıkları otoritaryenliğin üç temel önceliği bulunduğunu söylemişlerdir: (1) İstikrarsızlık ve düzensizlik riski karşısında güvenliğin önemi (yabancılar işimizi çalıyor, göçmenler kadınlarımıza saldırıyor, teröristler güvenliğimizi tehdit ediyor) (2) Geleneksel değerleri muhafaza etmek ve yaşam tarzımızı korumak için grup uymacılı̆̆ı (conformity) ('Avrupa değerlerine' yönelik tehditlere karşı 'Biz'i savunmak) (3) Grubu ve grubun geleneklerini koruyan güçlü lidere karşı sadık bir şekilde itaate olan ihtiyaç (Norris ve Inglehart, 2019, s. 7). Norris ve Inglehart, otoritaryenliği tanımlarken korku politikasının üzerinde dururlar: "Korku politikası, kişisel özgürlüklerden feragat etme anlamına gelse bile kabile için toplu güvenlik arayışını tetikler." Buna dayanak olarak Biz/Onlar ya da Halk/Öteki karşıtlıkları kullanılır. Biz veya halk genellikle milliyet ve vatandaşlık bağlarıyla tanımlanır ve ırk, din ve etnik köken, konum veya yaş, parti, cinsiyet gibi sembolik bağlar, grup içinde aidiyet ve sadakati kurarken, grup dışındakilerle sınırları ifade eder (Norris ve Inglehart, 2019, s. 7). Araştırmacılar farklı kavramlarla ifade etmiş olsalar da otoritaryenizmin temel niteliklerinin gelenekçilik, etnisiteye vb. dayalı bir biz tanımı; iç ve dış düşman tanımı; biz/öteki, dost/düşman, zayıf/güçlü gibi ikiliklere dayalı düşünme biçimi; güçlü lider anlayışı ve lidere itaat olduğu söylenebilir.

Son birkaç yılda popülizm kavramı üzerine de çok sayıda tartışma yürütüldüğüne, kitaplar ve makaleler yayınlandığına şahit oluyoruz. Latin Amerika'daki solcu başkanları, Avrupa'daki sağ partileri, ABD'deki sağcı ve solcu başkan adaylarını tanımlamak için kullanılan popülizm terimi (Mudde ve Kaltwasser, 2017, s. 1), Amerika Birleşik Devletleri' nin 2016 seçim kampanyalarında daha önce hiç olmadığı kadar zikredildi (Müller, 
2018, s. 13). Bununla birlikte kavramın gerek popüler kullanımında gerekse akademik kullanımında kafa karışıklı̆̆ı bulunduğunu, kavrama ilişkin yakın zamanlı akademik çalışmaların da kavramı tanımlamanın zorluklarından bahsederek başladıklarını görüyoruz (bkz. Anselmi, 2018; Müller, 2018; Mudde ve Kaltwasser, 2017).

Popülizm terimini anlamanın zorluklarından söz eden Jan-Werner Müller bir popülizm teorisine sahip olmadığımız gibi siyasal aktörleri hangi kriterler üzerinden popülist olarak tanımlayabileceğimizin de net olmadığını söyler; aynı zamanda popülizm teriminin siyasal kullanımlarının da kafa karıştırıcı olduğunu belirtir (2018, s. 14, 23). Bununla birlikte Müller de dâhil popülizm üzerine güncel tartışmalara katkı sunan yazarların terimin özünde neyi ifade ettiğine veya "popülist" olarak tarif ettikleri kişilerin nasıl bir dünya görüşüne sahip olduklarına ilişkin belirli noktalarda ortaklaştıklarını söylememiz mümkündür.

Cas Mudde'e göre (2004, s. 543-544) popülizm “toplumu nihai olarak 'saf/masum halk' ve 'yozlaşmış elitler' olarak iki homojen ve uzlaşmaz grup olarak düşünen ve siyasetin halkın genel iradesinin bir ifadesi olması gerektiğini öne süren bir ideolojidir." Mudde popülizmi Michael Freeden'ın ödünç aldığı kavramla “zayıf-merkezli [thin-centered] bir ideoloji" olarak tanımlar. Mudde ve Rovira Cristóbal Kaltwasser'a göre popülizm; faşizm, liberalizm, sosyalizm gibi "katt-merkezli" ("thick-centered") ya da "pür" ("full”) ideolojilerin aksine başka bir ideolojiye ya da daha geniş bir kitleye hitap eden politik projelerin tutunması için çok önemli olan ideolojik unsurlara eklemlenir ya da başka bir ideoloji içinde asimile olur. Oldukça farklı, hatta birbiriyle çatışan ideolojilerle bir arada görünen popülizm, çok da tutarlı bir ideolojik gelenek değildir. Mudde ve Kaltwasser'e göre, bu nedenle popülizm tek başına modern toplumların ürettiği sorunlara cevap sunamaz (Mudde ve Kaltwasser, 2017, s. 6).

Pippa Norris ve Ronald Inglehart (2019) ise popülizmin "kimin yönetmesi gerektiğine ilişkin birinci dereceden prensipleri yansıtan"; meşru gücün elitlere değil, 'halk'a dayandığını iddia eden bir "retorik tarzı" olarak anlaşılması gerektiğini söylemişlerdir. Yazarlara göre bu "farklı ideolojik değerlere ve ilkelere esnek bir şekilde uyum sağlayabilen bukalemun benzeri bir söylemdir." Sosyalist ya da muhafazakâr popülizm, otoriter veya ilerici popülizm gibi tanımlamalardan bahsedebilmemizin nedeni de budur (2019, s. 4). Müller ise popülizmin bir doktrin olmaktan ziyade kendi iç mantığına sahip "belirgin bir iddialar bütünü" olduğunu savunur. Müller'in popülizm tanımı halk/elit karşıtlı̆̆ı vurgusuyla Mudde ve Kaltwasser ile Norris ve Inglehart'in tanımlarıyla temelde benzerlik taşır: "Ben popülizmin siyasetin özgül bir ahlakçı bakışla tasavvur edilmesine dayandığını 
düşünüyorum. Yani, siyasal dünyanın, en nihayetinde kurgusal bir şekilde, ahlaken saf ve bütünleşmiş halk ile ahlaken aşağı olan yozlaşmış seçkinler arasında bir ayrım üzerinden algılanması" (2018, s. 25, 36). Görüldüğü gibi popülizm "zayıf-merkezli bir ideoloji”, bir "retorik tarzı" ya da "belirli bir iddialar bütünü" olarak tanımlansa da temelde halk/elit karşıtlığına dayandırılır.

Ancak böyle bir tanım çok geniş ve potansiyel olarak tüm siyasi aktörlere, hareketlere ve partilere uygulanabilir nitelikte olduğu için eleştirilir. Nitekim Müller'in belirttiği gibi böyle bir anlayışta elitleri eleştirenlerin tamamının popülist olarak tanımlanması gerekir. Bu nedenle tanımlamayı daraltmak ve netleştirmek için Mudde (2004, s. 543) ile Mudde ve Kaltwasser (2017, s. 7) popülizmin neyin karşısında konumlandığının altını çizerler. Yazarlara göre popülizm sadece elitizm değil, aynı zamanda çoğulculuk karşıtıdır. Popülistlerin halkı "tek, homojen" olarak tanımladığını söyleyen Müller de benzer bir noktaya vurgu yapar (2018, s. 15, 36). Bununla birlikte popülist liderler sadece kendilerinin sıradan halkın gerçek sesini yansıttığını savunurlar (Müller, 2018, s. 15; Norris ve Inglehart, 2019, s. 6). Popülistler ayn zamanda "popülist partileri desteklemeyenlerin her zaman erdemli ve ahlaklı olarak tanımladıkları halkın uygun bir parçası olmayacağını ima eder." Siyasi rakiplerini de halkın gerçek bir parçası olmamakla, hatta "halk düşmanı" olmakla itham eder (Müller, 2018, s. 15-16). Burada sınırlı bir "halk" tanımı vardır. Tıpkı Trump'ın "önemli olan tek şey halkın birleşmesidir, çünkü geriye kalanların bir önemi yoktur" (aktaran Müller, 2018, s. 38) sözlerinde olduğu gibi. "Halk" ve "geriye kalanlar" ayrımında insanların bir kısmı muğlak bir şekilde halk olarak tanımlanırken, bir kısmı bu tanımın dışında bırakılır. Ancak böyle bir halk fikri Müller'in belirttiği gibi tamamen bir fanteziden ibaret (2018, s. 16) olduğu gibi aynı zamanda çoğulculuk karşıtlığını barındırmaktadır.

Popülizme göre halk gibi elitler de "homojen"dir. Halkın "genel iradesine" karşı çalışan homojen ve yozlaşmış bir grubu oluşturan elitler çoğu popülist için, sadece politik elitleri değil ekonomik ve kültürel elitler ile medya elitlerini de kapsar (Mudde ve Kaltwasser, 2017, s. 11-12). "Ana akım medya 'sahte haber' üretir, seçimler 'hileli'dir, muhalif politikacılar 'hain'dir, siyasi partiler 'işlevsiz'dir, kamu sektörü bürokratları 'derin devlet'tir, hâkimler 'halk düşmanı'dır, protestocular parayla tutulmuştur, istihbarat servisleri 'yalancı'dır ve bilgi sızdırır, lobiciler 'yozlaşmış' tır, aydınlar 'kibirli liberaller'dir, anayasa 'hileli bir sistem'dir, Avrupa Birliği 'Brüksel bürokratları'dır, BM 'bir konuşma kulübü'dür" (Norris ve Inglehart, 2019, s. 4). Hedefte popülistlerin elit olarak tanımladığı kişiler ve gruplar ile onların yönetimindeki kuruluşlar vardır. Norris ve Inglehart'a göre popülist liderler bu düşmanlar karşısında "kendilerini uzun zamandır hâkim olan 
geleneklere meydan okumaya ve 'her zamanki siyaset'i darmadağın etmeye hevesli isyancılar olarak tasvir ederler" (Norris ve Inglehart, 2019, s. 4).

Popülist söylem ile otoritaryen değerlerin birleşimi son derece tehlikeli bir kombinasyon oluşturur. Norris ve Inglehart'ın belirttiği gibi popülist retorik insanların politikacılara, medyaya ve ana akım partilere olan güvensizliğini besleyerek liberal demokrasiye olan inancı aşındırıp şikâyetleri "yukarıya" yani elitlere karşı yönlendirirken, otoritaryenler biz/onlar ayrımı yaparak ve kaygıyı körükleyerek şikâyetleri "dışarıya" yani grubun değerlerini/normlarını tehdit ettiği düşünülen "günah keçisi" gruplara yönlendirirler. Bu da karşılıklı hoşgörüyü ve insanlığa olan toplumsal inancı aşındırır (Norris ve Inglehart, 2019, s. 7).

Lowenthal ve Guterman'ın Aldatmanın Peygamberleri (1949/1970) çalışmasında tanımladığı ajitatör tam olarak böyle bir kişidir. Bu çalışma da, Otoritaryen Kişilik (Adorno vd., 1950, 2003) gibi Studies in Prejudice projesinin bir parçasıdır. Yazarlar bu çalışmada o dönemde ABD'de Avrupa totalitarizmine sempati duyan, pro-faşist, komünizm karşıtı ve anti-Semitist on üç kamusal figürün radyo konuşmalarını, kitaplarını, konferans metinlerini ve yazılarını analiz ederek ajitatörlerin rolü, psikolojik teknikleri ve ara bulma mekanizmalarını ortaya koymuşlar ve ajitatörlerin metinlerinde yinelenen yirmi bir farklı tema belirlemiştir. Bu temaların günümüz otoritaryen popülizmini incelemek için de geçerliliğini koruduğunu söyleyebiliriz.

Lowenthal ve Guterman'ın ajitatör olarak tanımladı̆̆ı kişiler, irili ufaklı politik hareketlere ve periyodik yayınlara öncülük eden, sık sık politik demeçler verip konuşmalar yapan, çoğu Hitler ve Mussolini'ye duydukları hayranlığı ve anti-semitist olduklarını açıkça belirten "kendinden menkul" siyasi figürlerdir. Ajitatörlerin büyük çoğunluğu yerel düzeyde etkinliği olan kişilerdir; "kitleleri sürükleyen bir lider imajı taşımaktan çok, bir sahte ilaç şarlatanını andırırlar." Bir dolandırıcının pek çok karakteristik özelliğine sahiptirler. Halkın radikal bir değişikliğe karşı olan belirsizlik, kararsızlık, korku hisleri üzerine oynarlar (1970, s. 4). Yazarlara göre ajitatör, zaten var olan önyarg1 ve eğilimleri şekillendirir, doktrine eder ve sonuç olarak bunların eyleme dökülmesini sağlar. Yazarlar, ajitatörü yönlendiren içsel, bazen bilinçdışı mekanizmaları değerlendirmiş olsalar da bunların sosyolojik bir perspektiften anlaşılması gerektiğini savunurlar. Hiçbir ajitasyon tekniğinin politik ya da sosyal bağlamı dışında değerlendirilemeyeceğini söyleyen yazarlara göre ajitatörlerin anti-demokratik kitle manipülasyonu "demokratik bir toplum içsel bir yıkımla tehdit edildiğinde ortaya çıkar. Temel fonksiyonu her zaman aynıdır: Temel 
çıkarlarına aykırı saydıkları hedeflere doğru kitlelere önderlik etmek" (Lowenthal ve Guterman, 1970, s. xi, xv-xvii).

Aldatmanın Peygamberleri kitabı ajitatörün retorik taktiklerinin ortaya serildiği, dönemin tipik bir ajitatif konuşmasının metniyle başlar:

Amerika'nın sade, sıradan, içten ve mazlum insanları ne zaman günlük hayatlarının kontrolünün tümüyle düşmanların; komünistler, mülteciler, dönekler, sosyalistler ve vatan hainlerinin elinde olduğu gerçeğine uyanacak? Amerika'nın bu diş düşmanları, kelebeğin kozasının içine girip larvalarını yayan parazit böcekler gibidir. Koza açıldığında kelebek yerine paraziti buluruz. Bu akıllıca bir plandır ve eğer Amerikalılar silkelenip tüm bu düşmanlarıyla baş etmeye başlamazlarsa neyin çarptığını bile anlamadan boylu boyunca yerde bulacaklar kendilerini... Oğlunuzun, kızınızın ya da karınızın kanı, Yahudilerden, zencilerden ya da suçlulardan gelen kanla kirlenirse bu hoşunuza gider mi? (1970, s. 1).

Bu metin ajitatörlerin ortak niteliğini gözler önüne seren bir niteliğe sahiptir. Lowenthal ve Guterman'a göre ajitatörlerin aralarında ne tür farklılıklar olursa olsun dikkatli bir metin okuması tesadüfi olmayan benzerlikleri, karakteristikleri, tekrarlanan motifleri gösterebilmektedir. Sözgelimi ajitatör, dinleyicisiyle dışarıdan biri gibi yaklaşır, sanki onların içinden yükselmiş biri, onların dile getiremedikleri düşünceleri dile getiren biri gibi konuşur onlarla. İfadeleri çoğunlukla müphem ve ciddiyetten uzaktır (1970, s. 5). Belli bir hedef kitlesi yoktur, her Amerikalı onun potansiyel takipçisidir. Toplumsal eşitsizliklerden belirsiz bir çerçevede söz eder, ancak bir devrimcinin aksine bunları halkın hoşnutsuzluğunun ve yaşadığı sorunların asıl nedeni olarak da göstermez. Bunun yerine kategorik bir dış düşman tanımlar. Sınırsız kötülüğüyle tüm toplumsal çatışmaların temelini oluşturan bir düşman seti sunar (1970, s. 6-8).

Ajitatörün ekonomik, politik, kültürel ve ahlaki şikâyetleri vardır. Bu şikâyetler yığınının tümünde, belli duygularla ve karmaşık hislerle oynanır: Lowenthal ve Guterman bunu ajitasyonun duygusal temeli (emotional substratum) olarak tanımlar ve siniflandirır. Güvensizlik: Göçmenler olsun, enternasyonalistler olsun, "düşmanların” tümü, Amerikan "saflı̆̆ını" kullanmanın peşindedirler. Bă̆ımlılık: Halkın kendini çaresiz ve güçsüz hissetmesini dış düşmanların yarattığı bir durum olarak tanımlar; bu güçsüzlüğün yarattığı kaygıdan kurtulmak için güçlü bir lidere ihtiyaç olduğunu söyleyerek kendisine işaret eder. Dışlanmışlık: Tüm bu düşmanlar nedeniyle ABD halkı kendi yurdunda kendini dışlanmış hissetmektedir; halkın parasıyla yabancilar besleniyordur. Huzursuzluk: Devrimci bir hareket Amerikan halkının içinde bulunduğu bu durumdan yararlanırsa, sosyal değerler 
sarsılacaktır. Bu endişeyi yaratarak orta sınıf korkularını besler. Gözbağından kurtulma: Düşmanlara ve onların alt metinlerine, gizli ajandalarına, aldatma ve ikiyüzlülüklerine karşı halkın gözünü açık tutması, uyanık olması gerekir (Lowenthal ve Guterman, 1970, s. 13-14).

Ajitatörün "Amerika'nın sade, sıradan, içten ve mazlum insanları"nın karşısına yerleştirdiği düşmanlar arasında "nüfuzlu zenginler" ile "yozlaşmış hükümet" önemli bir yer işgal eder. $\mathrm{Bu}$, otoritaryen kişinin popülist söyleminin gösterenleri olarak değerlendirilebilir. Lowenthal ve Guterman'ın tarif ettikleri ajitatör, ülkenin "milyarder bankacılar" ile "Amerikan halkı" arasında bölünmüş olduğunu söyler. Yazarlar bu nedenle ajitatörün iddialarının komünistlerin fikirleriyle örtüşür gibi göründügünü söyleseler de burada çok önemli bir fark olduğunun altını çizerler, ajitatörler izleyicilerinin dikkatini kapitalizmin kendisi üzerine değil, bankerler üzerine yoğunlaştırır (Lowenthal ve Guterman, 1970, s. 41-42). Ajitatör yozlaştığını öne sürdüğü politikacılara ve hükümete de düşmandır. Ancak hükümet eleştirisi de hükümette görev alan kişilerle sınırlıdır, hükümetin temel yapısına ilişkin herhangi bir eleştiri getirmez. Bununla birlikte ajitatör "izleyicisinin kimliği belirsiz ve karşı konulamaz güçlerin ulusun kaderini belirleme şüphesi üzerine oynar" ve "geleneksel Amerikan bürokrasisi ve merkezileşme konusundaki güvensizliğini körükler" (Lowenthal ve Guterman, 1970, s. 46, 48).

\section{ABD’de Eski Söylemin Yeni Görünümü}

Donald Trump'ın kampanyalarının birçok yönden klasik otoritaryen hareketlerin özellikleriyle örtüştügüunü söyleyen Douglas Kellner'a göre Frankfurt Okulu, Trump döneminde Amerikan otoriter popülizmini anlamamıza yardımcı olabilecek bir model sunar (Kellner, 2016, s. 19, 27). Kellner, 1930'larda Avrupa faşizminin takipçileri gibi Trump'ın destekçilerinin de yıllar boyunca ekonomik sıkıntılar, siyasi yabancılaşma, aşağılanma gibi zorluklardan mustarip olduğunu; 2007-2008 küresel ekonomik krizinde birçok kişinin işini, evini, tasarrufunu kaybettiğini, Obama döneminde ise oldukça yavaş bir iyileşme yaşandığını söyler. Böyle bir ortamda insanlar siyasi bir kurtarıcı arayışına girmiş (Kellner, 2016, s. 21, 23), aşırı sağ demagoglar ise krizlerden kaynaklı güvensizliklerden ve korkulardan faydalanmışlardır (Fuchs, 2018a, s. 5-6).

Richard Wolin seçmenlerinin Trump'ı "hileli sistemi, Kongreyi ve yargıyı atlatabilecek siyasi bir kurtarıcı olarak" algıladığını söylerken Önyargı Üzerine Çalışmalar'ın otoriter eğilimlere sahip kişilerin neden komplo teorilerine ve sistemin hileli olduğuna inanmaya açık olduklarını anlamaya yardımcı olduğunu belirtir. Wolin'in söylediği gibi, bu çalışmanın “önyargının, demokratik kurumlara güvensizlikle pozitif korelasyonu 
olduğu"na ilişkin bulguları bugün hala geçerliliğini korumaktadır (Wolin, 2016). Günümüz güvensizlik ortamında Trump otoriter bir lider olarak otoritaryen popülist bir hareket seferber etmiştir (Kellner, 2016, s. 20). Wolin'in belirttiği gibi demagogun abartılı bir hitabete ve duygusalcılığa başvurması, ortalama, ezilmiş vatandaşın aklını karıştırmaya ve "politik mesih olarak demagog"a daha etkili bir şekilde bağlamaya yöneliktir. Demagog bunu başarmak için sorunların gerçek nedenlerini görünmez kılacak gösterişli dile dayalı bir söylem kullanır (Wolin, 2016); göçmenleri, mültecileri, tüm diğer azınlıkları günah keçileri ilan eder ve milliyetçiliği vaaz eder (Fuchs, 2018a, s. 5-6).

Bu durumu Lowenthal ve Guterman'in sözünü ettikleri otobüs analojisiyle birlikte düşünebiliriz. Kalabalık bir otobüste diğer yolcular tarafından itilen ve sıkıştırılan bir yolcu sesli bir şekilde rahatsızlığını dile getirir. Bunun üzerine ikinci bir yolcu otobüs şirketinin söz konusu hat için daha fazla otobüs tahsis etmesi gerektiğini söyler. Üçüncü yolcu ise bunun otobüs şirketiyle hiçbir ilgisinin olmadığını, "iyi İngilizce bile konuşmayan yabancılar" yüzünden bu halde olduklarını, onların "geldikleri yere geri gönderilmeleri gerektiğini" söyler. Lowenthal ve Guterman birinci yolcunun sözlerini "belirsiz bir şikâyet" olarak değerlendirirken, ikinci yolcunun bakış açısı "bir reformcunun veya devrimcinin çözümüdür", çünkü "ulaştırma hizmetlerinin hatalı organizasyonu" gibi son derece somut bir meseleye işaret eder. Yazarlar üçüncü yolcunun bakış açısını ise belirli bir konudaki "şikâyeti, yerleşik bir otoriteye karşı eylemin konusuna değil, zararlı yabancılar konusuna çeviren ajitatörün çözümü" olarak değerlendirirler (Lowenthal ve Guterman, 1970, s. 8-9). Donatella della Porta'nın (2017) günümüz için yaptığı değerlendirme de Lowenthal ve Guterman'ın analojisini anıştırır. Günümüzde neoliberalizmin yarattığı memnuniyetsizliğin farklı siyasal biçimlerde ortaya çıtı̆̆ını söyleyen della Porta'ya göre "solda memnuniyetsizliğin kaynağı evrensel ve sınıfsal sorunlara bağlanıyor. Sağda ise, aynı memnuniyetsizliğin dışlayıcı ve yabancı düşmanı bir söyleme dönüştüğü" görülmektedir (della Porta, 2017, s. 56-57).

Klasik Amerikan demagogları gibi Trump da elitlerin arkasında bırakıldıklarına inanan insanların korkuları, sıkıntıları ve öfkeleri üzerine oynar; onları harekete geçirmek için Wall Street'ten Meksika sınırından geçtiği iddia edilen göçmenlere kadar uzanan günah keçilerini hedef gösterir (Kellner, 2016, s. 22). Otoriter popülist bir lider olarak bir yandan elitler karşısında "halkın sesi" olduğunu iddia ederken bir yandan da "Önce Amerika" söylemini kullanır ve düşmanlar (ya da günah keçileri) karşısında "Amerikayı yeniden büyük yapma" vaadinde bulunur. Cleveland'da yaptığı adaylık konuşmasında kendi planıyla rakipleri arasındaki en önemli farkın kendilerinin "Önce Amerika" demeleri 
olduğunu söyleyen Trump amentülerinin küreselleşme değil, Amerikancılık olacağını söyleyerek kitleleri coşturmayı başarır. Amerika'nın “Önce Amerika” demeyen politikacılar tarafından yönetildiği sürece "hak ettiği saygı"yla karşılaşmayacağını söyleyen Trump (2016) göreve başlama töreninde de bu söylemi sürdürür (2017).

Ancak ne "Önce Amerika" ya da "sizin sesiniz olacağım" söylemi ne de "Amerikayı yeniden büyük yapma" vaadi yenidir. Lowenthal ve Guterman'ın geleceği gördügünü söyleyen Wolin, yazarların dönemin ajitatörünün konuşmasından yaptıkları alıntının Trump'in retoriğiyle olan benzerliğine dikkat çeker: "Hepinizin söylemek istediği ama söylemeye cesaretinin olmadığı şeyleri söylüyorum... Daha fazla uzatmadan ... toplumsal gövde içindeki ayartıcıları hadım etmeyi ve Amerika'yı bu talanın bir daha asla tekrarlamayacağı şekilde yeniden kurmayı öneriyoruz" (aktaran Wolin, 2016). Wolin'in belirttiği gibi daha 1940'larda demagoglar "şehirli elitler" ve "gerçek Amerikalılar" arasında ayrım yapma konusunda ustadırlar. Lowenthal ve Guterman'ın Aldatmanın Peygamberleri çalışmasında yer verdikleri şu popülist söylem bunu açıkça göstermektedir: "Bu hükümeti, bu şehirli züppelerin elinden alacağız ve iki ile ikinin dört olduğuna, Tanrının cennette olduğuna, İncil'in Dünya olduğuna hala inanan halka geri vereceğiz." Dolayısıyla Trump'ın "Amerikayı Geri Al" söyleminin de oldukça eski bir tarihi olduğunu söyleyebiliriz (Wolin, 2006; Lowenthal ve Guterman, 1970, s. 2). “Önce Amerika” sloganı veya başlı̆̆1 ise belki de Trump'ın söylemini geçmişin otoritaryenizmine bağlayan en güçlü örnektir. 1884 yılında bir Kaliforniya gazetesi İngilizlerle ticaret savaşı konusundaki bir makalenin başlığı olarak "Önce ve Her Zaman Amerika" başlığını kullanır. 1891 yılında New York Times "Cumhuriyetçi Parti'nin her zaman inandığı fikir, önce Amerika, sonra dünyanın geri kalanıdır" diye bir ifade kullanır. Cumhuriyetçi Parti ise 1894 yılında bu ifadeyi kampanya sloganı olarak kabul eder. Daha sonra yer altı faşist hareketlerle ayakta kalan slogan 1920'li yıllarda Ku Klux Klan'ın mottosu haline gelir (Churchwell, 2018). Bir rahip olan ve Büyük Depresyon yılları boyunca yerel bir popülist sağ hareketi yöneten Gerald L. K. Smith 1944 yılında kurmuş olduğu partiye "Önce Amerika” adını verir. Lowenthal ve Guterman'ın ajitatör olarak inceledikleri isimler arasında Smith de vardır (Lowenthal ve Guterman, 1970). Sarah Churchwell'in belirttiği gibi bir "köpek düdüğü" işlevi gören bu ifade, Amerikan muhafazakâr popülizminin patlamasının yeni bir şey olmadı̆̆ını gösterir. Amerikan tarihinin popülist demagojisinin kuşakları aşarak nasıl günümüze geldiğinin bir kanıtıdır (Churchwell, 2018). Burada yeni olan şey, sloganın hiç olmadığı kadar yaygin bir şekilde kabul görmesi ve yaygınlaşmasıdır. Bu yaygınlaşmada yeni medya ekolojisinin payı yadsinamaz. 
Wilhelm Reich Faşizmin Kitle Psikolojisi kitabında Hitler'in "kitlelere argüman, kanıt ve bilgi yoluyla değil ancak duygular ve inançlar yoluyla" (aktaran Fuchs, 2018b, s. 785) erişilebileceğine ikna olduğunu söylemiştir. Reich'ın iddiasının günümüz için de geçerli olduğunu rahatlıkla söyleyebiliriz. Günümüzde bu durum post-hakikat siyaseti olarak adlandırılmaktadır (Fuchs, 2018b, s. 785). Post-hakikat, kamuoyunu şekillendirmekte olgusal gerçeklerden ziyade duygulara ve inançlara seslenmenin daha etkili olduğu koşulları ifade eder. İçinde bulunduğumuz çağı post-hakikat rejiminin baskın olduğu bir çağ olarak nitelendiren yazarlara göre bu çağda, duygu ve inançlara dayalı "alternatif gerçekler", nesnel gerçekliklerin yerini almakta ve bu, politik üstünlük kurmanın bir aracına dönüşmektedir (McIntyr, 2018 ve Farkas ve Schou, 2018'den aktaran Taş ve Taş, 2018, s. 191192). “Önce Amerika” söylemini bu çerçevede düşünebiliriz. Post-hakikat siyaseti ve "Önce Amerika" söyleminin yeni medya ile oldukça sıkı bir bağı bulunmaktadır. Gerçek ile yalan haber sınırının bulanıklaştığı, kullanıcı türevli içeriklerin gerçeklik statüsü elde ettiği, kullanıcıların haber takibi için geleneksel medya yerine sosyal medyaya yöneldiği günümüzde, sosyal medya otoritaryenliğin yaygınlaşması için bir zemin oluşturabilmektedir.

\section{Aldatmanın Peygamberi Olarak Nicholas J. Fuentes}

Trump'in otoritaryen popülist takipçileri de politik yapılara ve sisteme, medyaya, ekonomik ve diğer elitlere öfke duyarlar (Kellner, 2016, s. 24) ve bu duygularını tıpkı Trump'ın yaptığı gibi demagojik bir dille yeni medya aracılığıyla paylaşırlar. Nicholas J. Fuentes'i, Trump'ın öfkeli takipçilerinden biri olarak kabul edebiliriz. Trump'la benzer bir söyleme sahip olan Fuentes' in üslubu da Trump'in gösterişli ve saldırgan konuşma üslubuyla benzerlik gösterir. Fuentes Youtube kanalında yayınladığı videolarında saatlerce neredeyse hiç nefes almadan konuşabilen bir otoritaryen popülist demagogdur. Klasik otoritaryen kişilikte olduğu gibi lidere koşulsuz itaatten yanadır, aynı zamanda batıl inançlara sahiptir, liderin kaderinin mistik olarak belirlendiğine inanır. Beyaz Saray Basın Danısmanı Sarah Sanders'ın "Tanrı Donald Trump'ın başkan olmasını istedi" sözlerini, "Bu ironik olmayan şekilde \%100 doğru” diye paylaşır (2019a).

Fuentes, Lowenthal ve Guterman'in ajitatör tanımına neredeyse kusursuz biçimde uymaktadır. Bu nedenle aşağıda, Fuentes'in popülist retoriğini analiz etmek amacıyla Lowenthal ve Guterman'ın ayrıştırdıkları kategorilerden yararlanılmıştır. Analiz için Fuentes'in Twitter sayfalarının, Youtube kanalının, kişisel web sitesinin ve çeşitli kişilere verdiği röportajların sağladığı zengin veri bütünü kullanılmıştır. 
Halk ve Elitler

1940'ların Amerikan ajitatörü topluluğa hitap ederken "biz Amerikalılar", "biz Hıristiyanlar" kalıplarını kullanırken "Amerikancılı" adına sınıfsal ve toplumsal farklılıkları açıkça reddeder: “... Amerikancılık Chicago'daki bir hendek kazıcısı ile Washington'daki bir Yüksek Mahkeme hâkimi kadar iyi tadı olan saf su gibidir" (Lowenthal ve Guterman, 1970, s. 96). Fuentes de kendi kimliğini millet ve din temelinde tanımlar. Yasmine Ghanem, Fuentes'le yaptığı söyleşide ona bir Hispanik olarak, Hispanikleri tecavüzcü ve suçlu olarak tanımlayan Trump'ı nasıl desteklediğini sorduğunda, Fuentes yüzde 25 Meksikalı olduğunu ama Hispanik olmakla Trump'ı desteklemek arasında hiçbir çelişki bulunmadığını ifade eder. Ailesi tarafından "Önce Amerika” ilkesiyle yetiştirildiğini belirten Fuentes, atalarının Meksika'yı Amerika'ya getirmek için değil, Amerikan olmak için terk ettikleri üzerinde durur (Ghanem, 2016).

Onun için halk Hristiyan beyaz rrktan ibarettir. Amerika'da yaşayan insanları beyazlar ve beyaz olmayanlar olmak üzere ikiye ayıran Fuentes, gerçek Amerikan halkının beyazlar olduğunu iddia eder. "People of Color" teriminin "beyaz karşıtı", "beyazlara karşı bir nefret" terimi ve politik bir icat olduğunu söyler. Fuentes'e göre açık tenli Anglo Saksonlar "hakiki 'Beyaz' Amerikanlar"dır. Gerçek Amerikan olmayanlar ise Hispanik ve Asyalı göçmenlerdir. Fuentes aynı zamanda izleyicinin korkusu üzerine oynar ve dinleyicisinin zihnine beyaz olmayanların beyaz ırka karşı birleşeceği korkusunu ekmeye çalışır: "Tarihte beyaz olmayan ırklar arasında da çatışmalar olmuştur: Siyah Amerikanlarla Afrikalı göçmenler, Porto Rikolularla Meksikalılar, Hindistanlılarla Pakiler, liste uzar gider. Ama bunların hepsi Geleneksel Beyaz Amerika'ya karşı mücadele etmek için birleşebilir..." (2019b) Fuentes için beyaz olmayanlar listesi sadece siyahlar ve göçmenlerden oluşmaz, Yahudileri de bu listeye dâhil eder ve "...beyaz olmayanların (Yahudiler de dâhil olmak üzere) Amerika'da önceliğe sahip olmak için Beyaz Hristiyanlara karşı meydan okuduğu” bir zamanda yaşadığımızı söyler (2019c). Böylelikle sadece beyazlık değil, Hristiyanlık da halkı tanımlayan bir unsur olarak karşımıza çıkmış olur.

Lowenthal ve Guterman'a göre ajitatör öteki tanımı yaparken izleyicinin derinlerdeki psikolojik duygularına hitap etmek için Hristiyanlığın evrenselci doğasını saptırır ve onu "Amerikancllık"la eşit endogamik bir din olarak görür (1970, s. 73-74). Kendisini düşmanlarının karşısında tanımlarken Hristiyanlığa başvuran Fuentes: “Bütün düşmanlarımız İsa Mesih'i militanca hor görürler, bu bile tek başına bir şeyler söylüyor"; “Pek çok insan bunu duymaktan hoşlanmaz, ama uygarlığımızı yeniden düzenleme 
şansımızın tek yolu Hristiyanlığa geri dönmemizdir" (2017a) sözleriyle Hristiyanlığı da halk anlayışına iliştirmiş olur.

Ajitatörün diğer özelliği çaresizlik ve pasiflik duygusundan mustarip insanlara hitap ettiğini varsaymasıdır (Lowenthal ve Guterman, 1970, s. 13). Bir ajitatör olarak Fuentes de sürekli biçimde beyaz halkın saldırı altında olduğu izlenimi vermeye çalışır. Beyaz ırkın baskı altında olduğu düşüncesi aslında bir komplo teorisine dayalıdır: "Beyaz Halka olan nefretleri köksüz, ulus ötesi, küreselci seçkinlerin gözünü kör etmiştir" (2017b); "Bütün bir insan ırkı yabancılar tarafından kazara yerinden edilmedi. Bu, köksüz elitlerin tasarımıydı" (2017c). Fuentes'in söylemini kurarken elitlerden sıkça faydalandığını görürüz. Fuentes elitler dediği grubu ya da kişileri başına çeşitli sıfatlar koyarak tanımlar: "Siyonistleri üzdüğü için" CNN'den kovulan Marc Lamont Hill ve "eşcinselleri üzdüğü için istifa eden" Kevin Hart'ı linç eden "kültürel ve politik elitler" (2018a), çatı katı süitinde yaşayıp göçmen karavanlarını umursamayan, "varlıklı elitler" (2018b), ülkenin ekonomik, sosyal ve politik olarak tamamen yıkılmasından sorumlu olan "küreselci elitler" (2018c), "Kürtleri, İspanyol göçmenleri veya NATO müttefiklerini terk etme konusunda gerçekten perişan görünenama 30 yıldır kendi ülkelerinde kendi halkını terk etme konusunda hiçbir endişe taşımayan" "siyasi elitler" (2018d) Fuentes'in hedefindedir. Ancak görüldüğü gibi somut bir grup olmaktan ziyade soyut, karmaşık bir düşman grubuna işaret eder. Bunu ajitatörün izleyicisinin kafasını karıştırmaya yönelik bir taktiği olarak okuyabiliriz.

Fuentes'in komplo teorilerine dayanan yaklaşımı 1940'ların ajitatörünün yaklaşımıyla büyük ölçüde benzerdir. 1940'ların ajitatörüne göre halk kandırılmaktadır; geniş kapsamlı ve dikkatle planlanmış bir politik komplonun kurbanıdır; bu komplo nedeniyle sistematik olarak kandırılmaya devam edecektir. Bankacılar, borsacılar, bürokratlar, tekelci şirketler uluslararası casuslar gibi sayısız düşmanın tuzağına tekrar ve tekrar düşmeleri kaçınılmazdır. Dünya karmaşık bir yerdir çünkü bu gibi kişi ve güçler onu karmaşıklaştırmaya, kavranamaz ve müdahale edilemez kılmaya çalışmaktadır. Ajitatör komplo teorilerine başvurarak takipçilerinin tedirginliğini ve savunmasızlık duygusunu harekete geçirir ve böylece onları bir yandan 'öteki' ve 'düşman' olarak konumlandırılan topluluklara tepkiye yönlendirirken bir yandan da lidere koşulsuz itaate yönlendirir (Lowenthal ve Guterman, 1970, s. 24-26).

Fuentes'in komplo teorilerinin merkezinde elitler kadar küreselcilik ve Yahudiler de bulunur. Karmaşık biçimde elitleri, küreselcileri ve Yahudileri birbirinin içine geçirir. Tüm bunları komplocu bir biçimde Amerikan halkını yok etmek için bir araya gelmişler gibi gösterir: "Küreselciler, kesinlikle ulusal bir kimliğin aksine uluslararası/ulus ötesi bir kimliği 
kucaklayan elitlerdir, doğal olarak birçok Yahudi, eğitimli bir şehir/diaspora halkı olarak bu kategoriye girer" (2018e). Beyazların baskı altında olduğu düşüncesini küreselcilikle ilişkilendiren Fuentes bununla yetinmeyerek beyaz halkın "ezilmişliğini" siyahların ezilmişliğiyle eş tutar: "Belki beyaz insanlar, bizden biri sistemin Küreselci politikasının bir sonucu olarak öldürüldügünde Siyahların Hayatı Değerlidir gibi 'miting' yapmalıyı" (2017d).

Küresellik terimi yabancı düşmanı, göçmen karşıtı ve anti-Semitik tonlara sahiptir. Stack'e göre terim "açık sınırları, çeşitliliği ve zayıf ulus devletleri severken, beyaz insanları, Hristiyanlığı ve kendi ülkesinin geleneksel kültürünü beğenmeyen" bir lobiye atıfta bulunur (Stack, 2017). Fuentes'in beyaz ırkın baskı altında olmasının müsebbibi olarak gösterdiği küreselcilik, ona göre medyayı da ele geçirmiştir. 1940'ların ajitatörünün halka bilgi sağlama misyonundaki medyanın, "halkın medyasının", "ulusun düşmanlarının elinde" olduğunu düşünmesi (Lowenthal ve Guterman, 1970, s. 12) gibi Fuentes de medyanın küreselcilerin elinde olduğunu iddia eder ve İlk Değişiklik hakkında izleyiciyle "bilgi" paylaşmadığı için medyayı suçlar. "Medyayı kim yönetiyor?" diye soran Fuentes cevabı da kendisi verir: "Küreselciler" (2017d) Lowenthal ve Guterman'ın tanımladığı ajitatörün evrenselcilik karşıtı olması gibi (1970, s. 32) Fuentes de ateşli biçimde küresellik karşıtlı̆̆ını savunur.

Fuentes'in söylemi, Adorno vd.'nin (1950) ayırt ettikleri otoritaryen kişiliğin özelliklerinden "otoritaryen saldırganlık"la ve Lowenthal ve Guterman'ın takipçilerinin öfkelerini yapıcı bir biçimde tasfiye etmelerine yardım etmek yerine "onların bu duyguları sözüm ona düşmanlara karşı şiddetle boşalttıkları fantezilerinin keyfini çıarmalarına izin ver(en)" ajitatörle (Lowenthal ve Guterman, 1970, s. 10) uyumlu görünmektedir. Fuentes'in, “Küreselcileri öldürme zamanı. CNN'i izlemek istemiyorum ya da CNN'in iflas etmesini istemiyorum, $\mathrm{CNN}^{\prime}$ in daha dürüst olmasını istemiyorum, $\mathrm{CNN}^{\prime}$ i yöneten insanların tutuklanmasını ve sınır dışı edilmesini ya da asılmasını istiyorum" (2017d) sözleri izleyiciyi kışkırtmaya ve izleyicinin öfkesini şiddete yönlendirmeye yöneliktir. Ayrıca bu sözlerin retorik bakımından da 1940'ların otoritaryen ajitatörüyle benzerlik taşıdığını söylememiz gerekir.

Lowenthal ve Guterman'ın tanımladıkları ajitatörün düşmanları sınırsız biçimde ahlak yoksunudur. Lüks tüketime gömülmüş, toplumun kaymağını yiyen bir Marksistler, göçmenler, sol kanat enternasyonalistler güruhu şampanyalarını patlatırken halkı sütsüz, tereyağsız, peynirsiz bırakmak istemektedirler (Lowenthal ve Guterman, 1970, s. 13). Benzer şekilde Fuentes'e göre TV'deki uzmanlar politikacılara karşı çok yumuşaktır çünkü onlar 
gerçek zorluklar için endişelenmek yerine "Manhattan' daki teras süitlerine çıkıp fincanı otuz dolarlık kahvelerini içerler" (2017d).

\section{Düşmanlar}

1940'ların Amerikan ajitatörü için sadece ekonomik ve siyasi elitler değil, komünistler, Yahudiler, yabancılar ve göçmenler de Amerika ve Hristiyanlığın düşmanlarıdır. Lowenthal ve Guterman'a göre “bütün sosyal değişim savunucuları gibi, ajitatör de takipçilerinin acı ve dertlerinden "düşman"1 sorumlu tutar. Fakat sosyal reformcu ya da devrimci için düşmanın yenilmesi, engellenmesi, devre dışı bırakılması bir son anlamına gelirken ajitasyonda bu kendi içinde bir sondur. "Çünkü düşman belirli bir hedefe ulaşmanın önündeki engel gibi değil, bir süper ezici güç, saf kötülüğün ve yıkıcılığın temsili, yarı biyolojik bir tür şeytan olarak düşünülür." O uzlaşılamazdır; toplumda herhangi yapıcı, olumlu bir işlevi olmayan yabancı bir cisim gibidir. Pişmanlığını kanıtlamak için geçebileceği herhangi bir uzlaşma köprüsü yoktur. Orada, sonsuza dek, kötülük aşkına kötüdür. Ajitatör bu çerçeve içine var olan düşman stereotiplerini yerleştirir; sayısız hedefi vardır. Onları komünistler, Naziler, Faşistler, Japonlar, sözde demokrasi yandaşları, enternasyonalistler, New Deal bürokratları ya da komünizm sempatizanı gazeteciler olarak adlandırır ve ekler: Sanmayın ki düşmanlarımız bu kadarla sınırlı, buna daha yüzlercesini ekleyebiliriz. "Fakat düşmanlarımızla gurur duyuyoruz, böyle kişi ve kurumlar tarafından nefret edilmek bir onurdur!" (Lowenthal ve Guterman, 1970, s. 38).

Ajitatörün özellikleri Adorno vd.'nin otoriter kişilik olarak tarif ettikleri kişilerin özellikleriyle uyumludur. Otoriter kişilik anti-demokratik değerlere ve azınlıklara karşı düşmanca bir tutuma sahiptir, her alanda kontrolü savunan otoriter kişilik insanlara ve akla güvenmez, yasal düzene de inanmaz. Adorno vd. o dönemin güncel çalışmalarının bir azınlık grubuna düşmanlık besleyen kişinin büyük ihtimalle diğer azınlıklara karşı da düşman olacağını söylerler. Yazarlara göre böyle bir genelleme için rasyonel bir temel yoktur ve belirli bir gruba yönelik önyarg1 ya da belirli bir grubu eleştirmeden külliyen kabullenme, o grubun üyeleriyle herhangi bir deneyim olmadığında mevcuttur (Adorno vd., 1950, s. 9). Bir "düşman listesi" ne sahip olmak alternatif politikalara ilişkin mantıklı bir değerlendirmenin yerine geçerek bu konudaki tartışmaları lüzumsuz kılar (Wolin, 2016).

Lowenthal ve Guterman'a göre ajitatörün milliyetçiliğinin muhafazakâr özelliklerinden biri, "her toplumsal sorunun iç-grup ve dış-grup çatışmasını içerdiği konusunda ısrar etmesi ve toplumsal problemleri içsel çatışmalar açısından analiz etmekten sürekli kaçınmasıdır." Örneğin işsizlik, istenmeyen yabancıların ülkeye akmasından 
kaynaklanır; gıda dağıtım sorununun ülke içinde satın alma gücündeki çeşitlilikle hiçbir ilgisi yoktur, "diğer ülkelerin doyumsuz iştahlarından" kaynaklanır (Lowenthal ve Guterman, 1970, s. 96). Göçmenler, ajitatöre göre yabanclar içinde en tehlikeli olanlardır. Bunlar yalnızca "pis işleri" yapmayı reddetmekle kalmayıp aynı zamanda yerli Amerikalıların güvenliğini de tehdit etmektedirler. Göçmenler, "Tannı' nın lanetlileri”, "daha iyi bir kaderi hak etmeyen sürgünler" olarak tanımlanır. Göçmenin evsizliği, ajitatörün takipçisinin bastırılmış içgüdülerinin eşdeğeri halini alır. Baskıya duyulan hınç ve yersiz yurtsuz insana duyulan hınç arasında psikolojik bir köprü kurulur: "Evi olmayan, zaten bir evi de hak etmiyordur" (Lowenthal ve Guterman, 1970, s. 50-51).

Lowenthal ve Guterman'a göre ajitatörün ekonomik şikâyetlerinin temelinde maddi ve manevi ürünlerin bol olduğu ama insanların hak ettiklerini elde edemediği iddiası vardır. Ajitatöre göre yabancılar sadece gerçek Amerikalıların parasını almakla kalmaz; onları işsiz de bırakır: "Göçmenler işlerini ele geçirirken doğma büyüme Amerikan vatandaşı yiyecek ekmek bulamadığı için intiharın eşiğindedir." Ajitatör, Amerikan vergi mükelleflerinin parasının kendisinden başka herkese yardım etmek için kullanılırken kendi milyonlarca işsizinin ihmal edildiğinden şikâyet eder. Kısaca şöyle der: "Yabancıları doyuruyoruz" (Lowenthal ve Guterman, 1970, s. 12-13).

Benzer şekilde göçü uluslararası kuruluşlarla ilişkilendiren Fuentes için “Bu 'göç' değildir. Bu, uluslararası kuruluşların denetimindeki soykırım unsurları tarafından Beyaz Irkın zorla yerinden edilmesidir" (2017e). Fuentes, RSBN TV'de yaptığı konuşmasında, Demokrat Parti'nin vergi mükelleflerinin ödediği milyarlarca doları "İngilizce bilmeyen insanları eğitmek", "yerlilerden daha yüksek oranda suç işleyen insanları hapsetmek" için, "yerli insanlardan daha yüksek oranda refahı tüketen insanların yiyecek, kıyafet, barınması" için harcanmasından şikâyet eder.

Fuentes, aynı konuşmada göçmenleri potansiyel terörist, katil, tecavüzcü ve parazit olarak tanımlar.

Söylediğim şey çok basit ve inkâr edilemez, vergilerimizi çalan insanlar artık bizim için çalışmıyor... Sınırın kapatılmadığı her gün, ülkenin güvenli olmadığı her gün, potansiyel katiller geliyor, potansiyel tecavüzcüler geliyor, ülkemizin gençliğini zehirleyen uyuşturucular sınır boyunca boşaltıllyor. Suçluları unut, Amerikan vatandaşlarına zarar verecek olan tüm o insanları bile unut, sınırdan akacak ve sadece burada olmalarıla, sadece parazit bir güç olarak, sosyal ve ekonomik altyapımıza zarar verecek milyonlarca, milyonlarca insanı düşün; dil konuşmayan insanlar, sizin pazarlanabilir becerileriniz yok, asimilasyon ya da entegrasyonla ilginiz yok... (2017f). 
Göçmenlerin "parazit" olarak tanımlanması sadece Fuentes'e özgü değildir. 1940’ların ajitatörü de göçmenleri Amerika'nın düzenini bozan "parazitler" olarak tanımlar. Lowenthal ve Guterman'a göre düşmanı parazit ya da böcek olarak tanımlamak insanlıktan çıkarmanın bir yoludur. Böylece göçmenler sempatiyi hak etmeyen, yok edilmesi gereken varlıklar olarak gösterilmeye çalışılır. Yazarlara göre ajitatör düşmanı suçlu, yozlaşmış, alçak bir hayvan, bir parazit olarak betimleyerek dinleyicilerinde derin bir nefret ve hayal kırıklığı uyandırır (Lowenthal ve Guterman, 1970, s. 50, 52).

Fuentes'in söylemi de nefret uyandırmaya dönüktür. Onun için beyaz olmayan tüm insanlar ve gruplar, özellikle göçmenler ve Müslümanlar beyaz Amerika'nın potansiyel düşmanlarıdır. Müslümanların ve göçmenlerin İlk Değişiklik (First Amendment) ${ }^{4}$ kapsamında korunmadığını iddia eden Fuentes'e göre “illk Değişiklik Müslümanlar için yazılmamıştır... Gelip bizi öldürmek isteyen barbarca bir ideoloji için yazılmamıştır; selefiler, Vahabiler, Suudi Kraliyet ailesi için değil Kalvinistler, Lutherciler ve Katolikler için yazılmıştır; göçmenler için değil, vatandaşlar için yapılmıştır" (2017d). Müslümanları potansiyel terörist ve katil ilan eden Fuentes, Müslümanların ABD'ye girişinin yasaklanmasını destekler (2018f).

Fuentes' in Müslüman ve göçmen karşıtı görüşleri Trump'ın politikası ile uyumludur. Adorno ve meslektaşlarının inceledikleri "otoritaryen kişilikler"in "yabancıları toplama kamplarına koyacaklarını" ya da "Siyonistleri sürgüne göndereceklerini" söylemeleri gibi, Trump da 11 milyon göçmeni sınır dışı etmekle tehdit eder ve ABD'ye girmek isteyen Müslümanlara genel bir yasak getirilmesini istediğini açıkça söyler (Wolin, 2016). Stereotipleri kullanan Trump da şöyle der: "İnsanlar geliyor ve ben sadece Meksikalılar demiyorum. Her yerden gelen katiller, tecavüzcülerden bahsediyorum..." (aktaran Fuchs, 2018, s. 1). Fuentes'in yaptığı gibi Trump da Müslüman karşıtı ve göçmen karşıtı politikasını savunmak için ulusal güvenlik ve asayiş konularına odaklanır: "Planım yurtta güvenlikle başlayacak - bu da güvenli mahalleler, güvenli sınırlar ve terörizmden korunma anlamına geliyor" (Trump, 2016).

Göçmenlerin yanında komünistler de düşman listesinde önemli bir yer işgal eder. Lowenthal ve Guterman'ın analiz ettiği ajitatör için kiliseleri yakan, Tanrı'nın elçilerine küfreden, kutsal sayılan her şeyi aşağılayan ve dini halkların afyonu gibi gösteren "Hıristiyan katili" Bolşevizm canavarı "Kızıllar", ajitatörün düşman listesinde baş sıradadır (1970, s. 38). Komünizm ve anarşizm Fuentes'in de düşmanlar listesindeki yerini alır:

\footnotetext{
${ }^{4}$ Amerika Birleşik Devletleri Anayasası'nın din özgürlüğü ve ifade özgürlügü hakkını devlet müdahalesinden koruyan 1791 tarihli İlk Değişikliğidir.
} 
“Komünizm/anarşizm, doğası gereği yabancı uluslararası bir etkinin ifadesidir. Hristiyanlığı asla etkisi altına alamamıştır, asla da alamayacaktır" (2017g).

1940'ların ajitatörü gibi Fuentes'e göre de en büyük düşmanlarından biri Yahudilerdir. Fuentes, Beyaz Amerika'nın en büyük düşmanlarından biri olarak gördüğü Yahudileri mütemadiyen tarihsel bir düşman olarak kurar: “USS Liberty'yi asla unutma! 34 Amerikan 'en yakın müttefikimiz' tarafından soğukkanlılıkla öldürüldü" (2017h), "Yahudilerin neden anavatanları hakkında makul derecede önyargılı olduklarını tam olarak anlayabilsek de her zaman ÖNCE AMERIKA'yı koymalıyı" (2017i).

Fuentes, 11-12 Ağustos 2017'de Virginia Eyaleti'ndeki Charlottesville'de neo-naziler, anti-semitist gruplar, ırkçılarla birlikte beyaz üstünlügünü savunan mitinglere katılmıştır (The New York Times, 19.08.2017). "Unite the Right" başlıklı miting, Konfederasyon simgesi General Robert E. Lee'nin heykelinin kaldırılmasını protesto etmek için planlanmıştır. Mitingde şiddet olayları yaşanmış, bir sürücünün arabasını karşı protestocu kalabalığın arasına sürmesiyle bir kişi ölmüş, birçok kişi yaralanmıştır. Fuentes, mitingi Twitter sayfasında "beyaz Amerika"ya karşı "kültürel soykırım”a dikkat çekmesi açısından bir "zafer" olarak nitelendirmiştir (2017j). Mitinge katılanlar "Yahudiler bizim yerimizi alamayacak" diye bağırırken (Gabbatt, 2017) Fuentes de “... bizim yerimizi alamayacaksınız. Köksüz uluslararası seçkinler beyaz kimliğinin dev dalgalarının geldiğini biliyor. Ve bu bir kez başlayınca bizi durduramayacaklarını biliyorlar. Ateş yükseliyor!" diyen bir mesaj paylaşmıştır (2017k).

Fuentes'e göre Yahudiler ayn zamanda kültürel yozlaşmadan da sorumludur: "Kürtaj, diş müdahale, çok kültürlülük, eşcinsellik ve kitlesel göç gibi sözüm ona 'Yahudi değerleri' liberal ve enternasyonalistlerin lehine görünüyor. Belki de bu etik ve dinsel ayrım bizim inandığımız kadar rastlantısal değildir" (2019e). Fuentes burada da liberaller, enternasyonalistler ve Yahudilerin, Amerikan değerlerini yok etmek için rastlantısal olmayan bir şekilde bir araya gelmiş kötü güçler olduklarına, bir komplonun parçaları olduklarına ilişkin izleyicisinin zihnine şüphe tohumları ekmeye çalışmaktadır.

\section{Sonuç}

Frankfurt Okulu düşünürlerinin 20. yüzyılın ilk yarısında yaptığı çalışmalar otoritaryen popülist söylem ve değerlerin günümüze özgü olmadığını göstermektedir. Avrupa'da yaşadıkları faşizm deneyiminin yaygınlaşmasından duydukları endişe, Okul düşünürlerini zorunlu olarak göç ettikleri ABD'de bu konuda çalışmalar yapmaya itmiştir. O dönemde ABD'de henüz güçlü bir siyasi harekete dönüşmemiş olan otoritaryen popülizm günümüz 
ABD'sinde Donald Trump'ın siyasetinde vücut bulmuştur. Günümüzde sadece siyasi liderler değil, aynı zamanda onların takipçisi olan ajitatörler de otoritaryen popülist söylemin yaygınlaşmasına katkıda bulunmaktadır. Bu söylemin bu denli yaygınlaşmasının önemli nedenlerinden birinin yeni medya olduğunu söyleyebiliriz. Nitekim bu yazıda ele alınan Nicholas J. Fuentes'in otoritaryen popülist söylemini Twitter ve Youtube'daki kendine ait kanalında sürdürdüğünü görmekteyiz.

Fuentes'in söylemini 1940'ların ajitatörünün sesinin günümüze ulaşmış yankısı olarak değerlendirebiliriz. Tipik ajitatör gibi Fuentes de tanımladığı düşmanları karmaşık biçimde birbiriyle ilişkilendirerek izleyicinin kafasını karıştırmaya dönük bir söylem geliştirmiştir. Lowenthal ve Guterman'ın altını çizdikleri gibi bu tür bir söylem bir delinin hezeyanları olarak görmezden gelinebilir, ancak kitleleri etkileyebilme tehlikesi içerdiği için dikkatli bir şekilde incelenmesi gerekir (1970, s. 4). Aynı zamanda otoritaryen popülist söylem ve değerlerin somut kamu politikaları ve yasalarda karşılığını bulduğu günümüzde bu söylemi deşifre etmeyi daha da önemli hale getirmektedir.

\section{Kaynaklar}

Adorno, T. W.; Frenkel-Brunswik, Else; Levinson, Daniel J.; Sanford, R. Nevitt (1950) The Authoritarian Personality. New York: Harper \& Brothers.

Adorno, T. W. (1943/2000). The Psychological Technique of Martin Luther Thomas' Radio Addresses. Stanford, California: Stanford University Press.

Adorno, T.W. (2003). Otoritaryen Kişilik Üstüne: Niteliksel İdeoloji İncelemeleri. (çev.) Doğan Şahiner. İstanbul: OM Yayınevi.

Anselmi, M. (2018). Populism: An Introduction. (çev.) Lauro Fano Morrisey. Londra ve New York: Routledge.

Appadurai, A. (2017). “Demokrasi Yorgunluğu." Büyük Gerileme, Zamanımızın Ruh Hali Üstüne Uluslararası Bir Tartışma. Haz. Heinrich Geiselberger. (çev.) Merisa Şahin vd. içinde. İstanbul: Metis. 17-29.

Borchers, C. (2016). “Trump TV Already exists. It's Called Right Side Broadcasting." The Washington Post. 22 Ekim 2016. https://www.washingtonpost.com/news/thefix/wp/2016/10/22/trump-tv-already-exists-its-called-right-side-

broadcasting/?noredirect=on\&utm_term=.0d027da99925 (Erişim Tarihi: 09.01.2019).

Churchwell, S. (2018). "End of The American Dream? The Dark History of 'America

First'." The Guardian. 21.04.2018. 
https://www.theguardian.com/books/2018/apr/21/end-of-the-american-dream-thedark-history-of-america-first (Erişim Tarihi: 26.10.2018).

della Porta, D. (2017). “Geç Neoliberalizmde İlerici ve Gerici Siyaset.” Büyük Gerileme, Zamanımızın Ruh Hali Üstüne Uluslararası Bir Tartışma. Haz. Heinrich Geiselberger. (çev.) Merisa Şahin vd. içinde. İstanbul: Metis. 44-58.

Fuchs, C. (2018a). Digital Demagogue: Authoritarian Capitalism in the Age of Trump and Twitter. Londra: Pluto Press.

Fuchs, C. (2018b). "Authoritarian Capitalism, Authoritarian Movements And Authoritarian Communication." Media, Culture E Society, 40(5): 779-791.

Fuentes, N. J. [@NickJFuentes]. (2017a) (03.10.2017). A lot of people don't like to hear that, but the only way to reorganize our civilization is to get back to Christianity. [Tweet]. https://twitter.com/NickJFuentes/status/915259820118245376 (Erişim Tarihi: 12.10.2017)

Fuentes, N. J. [@NickJFuentes]. (2017b) (03.10.2017). The hatred against the White People has blinded the rootless, transnational, globalist elites.

[Tweet]. https://twitter.com/NickJFuentes/status/915259820118245376 (Erişim Tarihi: 12.10 .2017$)$

Fuentes, N. J. [@NickJFuentes]. (2017c) (02.10.2017). An entire human race was not accidentally displaced by foreigners. This was the design of the rootless elite. [Tweet]. https://twitter.com/NickJFuentes/status/914700282604421121 (Erişim Tarihi: 12.10 .2017$)$

Fuentes, N. J. [@NickJFuentes]. (2017d) (18.09.2017). Maybe white people should "demonstrate" like Black Lives Matter every time one of ours is killed as a result of systemic Globalist policy.

[Tweet]. https://twitter.com/NickJFuentes/status/909960585814691841 (Erişim Tarihi: 14.01.2019)

Fuentes, N. J. (2017d) Trump Fan Wants CNN "Globalists" Hanged. [Video dosyasi]. https://www.youtube.com/watch?v=4zcz2tbePnI\&t=7s (Erişim Tarihi: 14.09.2017)

Fuentes, N. J. [@NickJFuentes]. (2017e) This is not 'immigration“. This is the forced displacement of White Race by the genocide elements under the control of international organizations.

[Tweet]. https://twitter.com/NickJFuentes/status/914702090424942593 (Erişim

Tarihi: 11.10.2017) 
Fuentes, N. J. (2017f) Live: America First With Nicholas J Fuentes 4/25/17. [Video Dosyası]. http://rsbn.tv/live-america-first-with-nicholas-j-fuentes-42517/ (Erişim Tarihi: 09.10.2017)

Fuentes, N. J. [@NickJFuentes]. (2017g) Communism / anarchism is by its very nature an expression of a foreign international influence.

[Tweet]. https://twitter.com/NickJFuentes/status/913709333443153920 (Erişim

Tarihi: 11.10.2017)

Fuentes, N. J. [@NickJFuentes]. (2017h) Never forget USS Liberty! 34 The American was killed in cold blood by our closest ally.

[Tweet]. https://twitter.com/NickJFuentes/status/918137557053067265 (Erişim

Tarihi: 11.10.2017)

Fuentes, N. J. [@NickJFuentes]. (2017i) Although we can fully understand why Jews are reasonably prejudiced about their homeland, we should always put AMERICA FIRST.[Tweet].https://twitter.com/NickJFuentes/status/917845716252397569

(Erişim Tarihi: 11.10.2017)

Fuentes, N. J. [@NickJFuentes]. (2017j) (19.08.2017). Charlottesville was a victory if only for bringing attention to the cultural genocide being committed nationwide against white America.

[Facebook post]. https://twitter.com/NickJFuentes/status/898979291408596995

(Erişim Tarihi: 11.10.2017)

Fuentes, N. J. [@NickJFuentes]. (2017k) (12.08.2017). Wow - what an incredible rally here in Charlottesville.

[Tweet]. https://www.facebook.com/nicholas.fuentes.71/posts/1148040112007632

(Erişim Tarihi: 11.10.2017)

Fuentes, N. J. [@NickJFuentes]. (2018a) (06.12.2018). The Right is scared to say this even though the Left shouts it from the rooftops, but our time can be framed, obviously, as a challenge by nonwhites (including Jews) against White Christians for primacy in America. [Tweet]. https://twitter.com/NickJFuentes/status/1087126250550894593 (Erişim Tarihi: 13.02.2019)

Fuentes, N. J. [@NickJFuentes]. (2018b) (24.10.2018). Why worry about a flood in the basement when you live in the penthouse suite? The operative word is bifurcation. In the future, the wealthy elite will pay a substantial premium to escape the consequences of their actions. 
[Tweet]. https://twitter.com/NickJFuentes/status/1055000725279924224 (Erişim Tarihi: 12.02.2019)

Fuentes, N. J. [@NickJFuentes]. (2018c) (04.02.2018). The globalist elites responsible for the complete destruction of our country- economically, socially, and politically -are the extremists, not us!

[Tweet]. https://twitter.com/NickJFuentes/status/960183623440896000 (Erişim

Tarihi: 12.02.2019)

Fuentes, N. J. [@NickJFuentes]. (2018d) (22.12.2018). The American political elite seems to get really torn up about abandoning foreigners like the Kurds or Hispanic immigrants or NATO allies-

[Tweet]. https://twitter.com/NickJFuentes/status/1076632417971113986 (Erişim

Tarihi: 12.02.2019)

Fuentes, N. J. [@NickJFuentes]. (2018e) (07.06.2018). The Left sees "Globalism" as a dog whistle for Jewry- not totally true.

[Tweet]. https://twitter.com/NickJFuentes/status/1004967730355867650 (Erişim Tarihi: 12.02.2019)

Fuentes, N. J. (2018f) Muslim Ban NOW and Live Primary Coverage Feat. McFeels and Bryden I America First Ep. 188.

[Video dosyas1]. https://www.youtube.com/watch?v=iTg0tTSDO8A (Erişim Tarihi: 12.02.2019)

Fuentes, N. J. [@NickJFuentes]. (2019a) (30.01.2019). This is unironically 100\% correct. [Tweet]. https://twitter.com/NickJFuentes/status/1090735655980797956 (Erişim Tarihi: 12.02 .2019$)$

Fuentes, N. J. [@NickJFuentes]. (2019b) (09.02.2019). Particularly in the American context, "POC" is intended to distinguish black Americans and the recent Hispanic/Asian immigrants from the characteristically light-skinned Anglo Saxon, the original "White" American.

[Tweet]. https://twitter.com/NickJFuentes/status/1094242069462335488 (Erişim

Tarihi: 13.02.2019)

Fuentes, N. J. [@NickJFuentes]. (2019d) (06.12.2018). As a proud black man myself, I take extreme umbrage to the high tech lynching of my free-thinking brothers at the hands of the cultural and political elite.

[Tweet]. https://twitter.com/NickJFuentes/status/1070928310203543552 (Erişim

Tarihi: 12.02 .2019$)$ 
Fuentes, N. J. [@NickJFuentes]. (2019e) (07.102.2019). It seems like so-called “Jewish values" tend to favor liberal \& internationalist positions like abortion, foreign intervention, multiculturalism, homosexuality, and mass immigration. [Tweet]. https://twitter.com/NickJFuentes/status/1093628620873052160 (Erişim Tarihi: 12.02 .2019$)$

Gabbatt, A. (2017). 'Jews will not replace us': Vice film lays bare horror of neo-Nazis in America. The Guardian.

https://www.theguardian.com/us-news/2017/aug/16/charlottesville-neo-nazis-vicenews-hbo (Erişim Tarihi: 02.03.2019).

Ghanem, Y. (2016). “We Spoke to Nicholas Fuentes, BU's Trump Supporter Everyone is Talking About." https://thetab.com/us/bu/2016/11/08/nicholas-fuentes-bu-trumpsupporter-9074 (Erişim Tarihi: 09.01.2019).

Horkheimer, M. vd. (1936/2002). "Authority and the Family." Critical Theory: Selected Essays (çev.) Matthew J. O'Connell içinde. New York: Continuum. 47-128.

Kejanlığlu, D. B. (2018). "Persistence or return of the 'Prophets of Deceit'?" Yayınlanmamış bildiri. ECREA $7^{\text {th }}$ European Communication Conference. 1 Kasım 2018. Lugano, İsviçre.

Kellner, D. (2016). American Nightmare: Donald Trump, Media Spectacle, and Authoritarian Populism. Rotterdam, Boston ve Taipei: Sense Publishers.

Lowenthal, L. ve Guterman, N. (1970). Prophets of Deceit: The Study of the Techniques of the American Agitator. New York: Harper \& Brothers.

Lowenthal, L. (1987). False Prophets: Studies on Authoritarianism. Londra ve New York: Routledge.

MacWilliams, M. C. (2016). “Who Decides When The Party Doesn't? Authoritarian Voters and the Rise of Donald Trump." PS: Political Science and Politics 49 (4): 716-21.

Manucci, L. (2017). "Populism and the Media." The Oxford Handbook of Populism. Cristobal Roviar Kaltwasser, Paul Taggart, Paulina Ochoa Espewo ve Pierre Ostiguy (ed.) içinde. New York: Oxford University Press. 558-582.

Morelock, J. (ed.) (2018). Critical Theory and Authoritarian Populism. Londra: University of Westminster Press.

Mudde, C. (2004). “The Populist Zeitgeist." Government And Opposition, 39 (4): 541-563.

Mudde, C. ve Kaltwasser, C. R. (2017). Populism: A Very Short Introduction. New York: Oxford University Press.

Müller, J. W. (2018). Popülizm Nedir? (çev.) Onur Yıldız. İstanbul: İletişim. 
Norris, P. ve Inglehart R. (2019). Cultural Backlash: Trump, Brexit and the Rise of Authoritarian Populism. New York: Cambridge University Press.

Rensmann, L. (2017). The Politics of Unreason: The Frankfurt School and the Origins of Modern Antisemitism. New York: Suny Press.

Stack, L. (2017). "Alt-Right, Alt-Left, Antifa: A Glossary of Extremist Language." The New York Times. 15.08.2017. https://www.nytimes.com/2017/08/15/us/politics/altleft-alt-right-glossary.html (Erişim Tarihi: 12.10.2017)

Şahiner, D. (2003). “Sunuş." Otoritaryen Kişilik Üstüne: Niteliksel İdeoloji İncelemeleri. Adorno, T.W. (çev.) Doğan Şahiner içinde. İstanbul: OM Yayınevi. 7-10.

Taş, O. ve Taş, T. (2018). “Post-Hakikat Çağında Sosyal Medyada Yalan Haber ve Suriyeli Mülteciler Sorunu." İleti-ş-im 29: 183-207.

The New York Times (2017). "The Fight for the White Race': What Some of the Charlottesville Rally Participants Stand For." 19.08.2017. https://www.nytimes.com/interactive/2017/08/19/us/charlottesville-quotes.htmlb (Erişim Tarihi: 10.10.2017)

Trump, D. (2016). Full speech: Donald Trump accepts GOP nomination, Part 2. [Video dosyas1]. https://www.youtube.com/watch?v=OjiT0H7yoVs

Trump, D. (2017). Trump: America first and only America first. [Video dosyas1]. https://www.youtube.com/watch?v=dIaoZqMrbCo

Wolin, R. (2016). “Our 'Prophet of Deceit', WWII-era Social Scientists Explained Trump's Appeal." The Chronicle Review. 30.10.2016. https://www.chronicle.com/article/OurProphet-of-Deceit/238176 (Erişim Tarihi: 10.01.2019) 